\title{
IMPLEMENTASI PENEGAKAN HUKUM PIDANA TERHADAP OKNUM TNI YANG MEMFASILITASI PELAKU TINDAK PIDANA NARKOTIKA BERDASARKAN UNDANG-UNDANG NOMOR 31 TAHUN 1997 TENTANG PERADILAN MILITER
}

\author{
Riky Pribadi ${ }^{1}$ \\ Danny Rahadian Sumpono ${ }^{2}$
}

\begin{abstract}
ABSTRAK
Pengguna narkotika di zaman sekarang ini tidak hanya dilakukan oleh masyarakat sipil namun juga dilakukan oleh militer yang pada hakikatnya bertugas untuk menjaga keutuhan bangsa dan negara. Adapun tujuan penelitian ini untuk mengetahui dan memahami bagaimana penegakan hukum pidana militer terhadap oknum Tentara Nasional Indonesia yang memfasilitasi pelaku tindak pidana Narkotika dan untuk mengetahui dan memahami faktor-faktor apa saja yang menyebabkan oknum Tentara Nasional Indonesia sehingga bisa memfasilitasi peredaran Narkotika serta untuk mengetahui dan memahami upayaupaya yang dilakukan oleh ankum (atasan yang berhak menghukum) terhadap oknum Tentara Nasional Indonesia yang memfasilitasi pelaku tindak pidana Narkotika. Dalam hal penulisan skripsi ini agar dapat mempermudah dalam proses penelitian, penulis menggunakan beberapa teori seperti Teori Negara Hukum, Teori Keadilan, Teori Kedisiplinan, dan Teori Hukum Pembangunan.

Metode yang digunakan dalam penelitian skripsi ini adalah metode pendekatan yuridis normatif yaitu pendekatan atau penelitian hukum yang menggunakan sumber-sumber data primer, sekunder dan tersier seperti peraturan perundang-undangan, sejarah hukum, perbandingan hukum, teori-teori hukum dan pendapat-pendapat sarjana hukum yang berhubungan.

Berdasarkan hasil penelitian yang dilakukan oleh penulis bahwa Penegakan hukum pidana terhadap pelaku penyalahguna narkotika golongan I oleh Oknum TNI yang memfasilitasi pelaku Tindak Pidana Narkotika di lingkungan militer masih belum efektif sesuai dengan aturan hukum yang berlaku dan masih terdapat beberapa kendala dalam mengatasi perkara. Faktor-faktor yang menyebabkan Anggota Militer yang memfasilitasi bahkan menggunakan Narkotika dapat kita lihat dari beberapa faktor ini, yang pertama Anggota Militer tersebut karena tingkat pemahamanya terhadap hukum dalam dirinya terbatas dan tingkat kesadaran terhadap hukumnya kurang dan yang kedua terjadinya suatu pelanggaran dan kejahatan terjadi karena adanya niat dan kesempatan, yang ketiga faktor individu yang di tekan berbagai tekanan hidup, faktor sosial (lingkungan sekitar), serta faktor ketersediaan Narkotika. Upaya yang dilakukan oleh Ankum terhadap anggota militer yang memfasilitasi tindak pidana narkotika sesuai dengan kewenanganya selaku Ankum mempunyai kewenangan untuk menjatuhkan hukuman disiplin kepada setiap Prajurit Tentara Nasional Indonesia yang berada di bawah wewenang komandonya apabila Prajurit Tentara Nasional Indonesia tersebut melakukan pelanggaran hukum disiplin.
\end{abstract}

\footnotetext{
${ }^{1}$ Dosen Fakultas Hukum Universits Majalengka, email : rikypribadi87@unma.ac.id ${ }^{2}$ Mahasiswa Fakultas Hukum Universitas Majalengka,email dannyrahadian26@gmail.com
} 
PRESUMPTION of LAW

Volume 3 Nomor 1 April 2021

Fakultas Hukum Universitas Majalengka

\section{Kata Kunci : Penegakan Hukum, Oknum TNI , Narkotika.}

\section{A. Latar Belakang Masalah}

Tentara Nasional Indonesia merupakan suatu sistem pertahanan negara dan merupakan alat negara yang mempunyai tugas mempertahankan, melindungi, dan mampu memelihara keutuhan serta kedaulatan negara, serta Tentara Nasional Indonesia dapat memberikan pengayoman terhadap masyarakat dan memberikan contoh untuk tidak menyalahgunakan narkotika, dimata hukum semua orang sama tidak mengenal pejabat atau pegawai rendahan tidak mengenal kaya atau miskin sebagaimana di uraikan dalam Pasal 28D ayat (1) KUHPM yaitu "Setiap orang berhak atas pengakuan, jaminan, perlindungan, dan kepastian hukum yang adil serta perlakuan yang sama di hadapan hukum".

Uraian diatas di implementasikan dalam asas hukum acara pidana yaitu, Semua orang diperlakukan sama di depan hukum (equality before the law). Asas ini dianut oleh semua negara yang berdasarkan hukum (rechtstaat), dan asas ini dinyatakan secara tegas dalam Pasal 5 ayat (1) Undang-Undang Nomor 4 Tahun 2004 tentang Kekuasaan Kehakiman, yaitu "Pengadilan mengadili menurut hukum dengan tidak membedabedakan orang". 3

Dengan demikian penegakan hukum di bidang hukum militer harus semakin dimaksimalkan. Sebagaimana diketahui bersama bahwa hukum militer sebagai subsistem dari sistem pertahanan keamanan negara perlu mengatur secara tegas mengenai operasionalisasi dari tatanan kehidupan bela negara yang melahirkan pertahanan keamanan rakyat semesta. Tatanan kehidupan bela negara mencakup penyelenggaraan seluruh daya kemampuan bangsa dan harus disusun, diarahkan serta dikerahkan secara terpadu dan terkendali baik mengenai tenaga manusia, fasilitas, peralatan maupun jasa dan ruang wilayah. Arah pengembangan hukum militer menuju pada terciptanya keserasian antara penyelenggaraan kesejahteraan dan penyelenggaraan keamanan dalam rangka mewujudkan wawasan nusantara serta ketahanan nasional, guna menjamin eksistensi kehidupan berbangsa dan bernegara yang bertujuan membangun manusia seutuhnya. ${ }^{4}$

Seorang militer adalah alat pertahanan negara, dimana militer yang seharusnya menjaga ketentraman dan keamanan negara berdasarkan Undang-Undang Nomor 34 Tahun 2004 tentang Tentara Nasional Indonesia, tidak seharusnya berbuat suatu tindakan yang bertentangan dengan hukum atau melawan hukum. Kasus-kasus yang menimpa pada seorang militer yang melakukan sebuah tindak pidana, baik secara umum maupun khusus dibedakan secara khusus di lingkup peradilannya. Karena hukum militer itu sendiri merupakan salah satu daripada hukum khusus, maka sistem peradilannya juga secara khusus. Kasus-kasus yang menjerat seorang militer sebagai subjek hukum pidana tersebut disidangkan dan diadili secara khusus di Pengadilan Militer.

Anggota TNI yang melakukan tindak pidana narkotika ataupun yang mengedarkannya akan dijatuhi sanksi pidana sesuai dengan yang diatur

\footnotetext{
${ }^{3}$ Amirroedin Sjarif, Disiplin Militer dan Pembinaannya, Ghalia Indonesia, Jakarta, 1982, hlm. 17.

${ }^{4}$ Suhadi, Pembahasan Perkembangan Pembangunan Hukum Nasional Tentang Militer dan Bela Negara, Badan Pembinaan Hukum Nasional Tentang Hukum Militer dan Bela Negara, Jakarta, 1996, hlm. 2.
} 
dalam Undang-Undang Nomor 35 Tahun 2009 tentang Narkotika apabila terbukti melakukan tindak pidana penyalahgunaan Narkotika. Sesuai dengan Pasal 6 KUHPM, terhadap anggota militer yang melakukan tindak pidana selain dijatuhi pidana pokok juga dapat dijatuhi pidana tambahan. Jenis pidana tambahan tersebut berupa pemecatan dari dinas militer, penurunan pangkat dan pencabutan hak-hak tertentu. Untuk pidana tambahan yang berupa pemecatan dinas dari militer dan penurunan pangkat tentunya tidak diatur dalam hukum pidana umum. Kedua jenis pidana tambahan ini adalah murni bersifat kemiliteran dan sekaligus merupakan pemberatan pemidanaan bagi anggota militer.

Beberapa kasus yang terjadi pada anggota militer salah satunya yaitu ditemukannya anggota militer yang memfasilitasi terjadinya tindakan kejahatan penyalahgunaan narkotika yang dilakukan oleh JTJ sebagai anggota Tentara Nasional Indonesia berpangkat SERMA. Tututan Oditur Militer kepada JTJ terdakwa telah terbukti secara sah dan meyakinkan bersalah melakukan tindak pidana setiap penyalahgunaan narkotika golongan 1. Bahwa JTJ menjadi prajurit TNI AU sejak tahun 1999, pada awalnya JTJ selaku terdakwa dalam kasus ini mendapatkan narkotika jenis golongan 1 tersebut dari temannya yang berinisal $\mathrm{AB}$ yang pada awalnya AB hanya memberi secara cuma-cuma kepada JTJ untuk menghisap atau menggunakan narkotika jenis golongan 1 tersebut, bahwa pada tanggal 30 November tahun 2016 sekira pukul 22.00 WIB JTJ menelpon temannya (pemakai) dengan tujuan untuk menawarkan sabu-sabu (narkotika jenis golongan 1) dengan harga Rp.450.000,- dengan jumlah sabu + 1/4 gr.

Dengan demikian siapapun pelakunya yang melakukan pelanggaran tindak pidana Narkotika tetap akan mendapatkan sanksi hukum sesuai dengan ketentuan yang berlaku sekalipun hal itu dilakukan oleh Tentara Nasional Indonesia maupun Polri. Dewasa ini tidak sedikit para penegak hukum yang terlibat dalam kejahatan narkoba.

Narkotika atau nama lazim yang sering diketahui oleh masyarakat berupa narkoba tidak selalu diartikan negatif, didalam ilmu kedokteran Narkotika dengan dosis yang tepat digunakan sebagai obat bagi pasien. Selain narkoba, istilah lain yang diperkenalkan khususnya oleh Kementerian Kesehatan Republik Indonesia adalah Napza yang merupakan singkatan dari Narkotika, Psikotropika, dan Zat Adiktif. Sudarto mengatakan bahwa kata Narkotika berasal dari perkataan Yunani "Narke", yang berarti terbius sehingga tidak merasa apa-apa. ${ }^{5}$

Sementara menurut Pasal 1 Angka 1 Undang-Undang Nomor 35 Tahun 2009 tentang Narkotika, pengertian Narkotika adalah : "Zat atau obat yang berasal dari tanaman atau bukan tanaman, baik sintetis maupun semisintetis, yang dapat menyebabkan penurunan atau perubahan kesadaran, hilangnya rasa, mengurangi sampai menghilangkan rasa nyeri, dan dapat menimbulkan ketergantungan". 6

Seperti kasus tersebut diatas, bahwa masalah peredaran dan penyalahgunaan narkotika di lingkungan militer harus mendapat penanganan yang serius, karena hal ini bisa menyebabkan rusaknya moral prajurit militer dan merusak citra kesatuan. Oleh karena itu, kewaspadaan

\footnotetext{
${ }^{5}$ Mohammad Taufik Makarao, Tindak Pidana Narkotika, Ghalia Indonesia, Jakarta,
} 2003, hlm. 17.

${ }^{6}$ Pasal 1 Angka 1 Undang-Undang Nomor 35 Tahun 2009 tentang Narkotika. 
akan peredaran narkotika harus lebih ditingkatkan lagi, sehingga penanggulangan terhadap tindak pidana penyalahgunaan narkotika dapat dilakukan secara efektif dan efisien.

Berdasarkan apa yang telah diuraikan tersebut diatas, maka penulis tertarik untuk melakukan penelitian yang disusun dalam bentuk Skripsi dengan judul "IMPLEMENTASI PENEGAKAN HUKUM PIDANA TERHADAP OKNUM TNI YANG MEMFASILITASI PELAKU TINDAK PIDANA NARKOTIKA BERDASARKAN UNDANGUNDANG NOMOR 31 TAHUN 1997 TENTANG PERADILAN MILITER.

\section{B. Rumusan Masalah}

Sesuai dengan latar belakang yang telah diuraikan diatas, maka identifikasi masalah penelitian ini ditetapkan sebagai berikut :

1. Bagaimana prosedur penegakan hukum pidana militer terhadap oknum Tentara Nasional Indonesia yang memfasilitasi pelaku tindak pidana Narkotika?

2. Faktor-faktor apa saja yang menyebabkan oknum Tentara Nasional Indonesia sehingga bisa memfasilitasi peredaran Narkotika?

3. Bagaimana upaya yang dilakukan oleh ankum (atasan yang berhak menghukum) terhadap oknum Tentara Nasional Indonesia yang memfasilitasi pelaku tindak pidana Narkotika?

\section{Tujuan Penelitian}

Adapun tujuan dalam hal penelitian ini yaitu untuk menambah wawasan pengetahuan dan pemahaman penulis akan arti pentingnya ilmu hukum dalam teori dan praktik menganalisis masalah hukum. Dan berdasarkan identifikasi masalah di atas, maka tujuan penelitian ini ditetapkan sebagai berikut :

1. Untuk mengetahui dan memahami prosedur penegakan hukum pidana militer terhadap oknum Tentara Nasional Indonesia yang memfasilitasi pelaku tindak pidana Narkotika.

2. Untuk mengetahui dan memahami faktor-faktor apa saja yang menyebabkan oknum Tentara Nasional Indonesia sehingga bisa memfasilitasi peredaran Narkotika.

3. Untuk mengetahui dan memahami upaya-upaya yang dilakukan oleh ankum (atasan yang berhak menghukum) terhadap oknum Tentara Nasional Indonesia yang memfasilitasi pelaku tindak pidana Narkotika.

\section{Kerangka Pemikiran}

Indonesia adalah Negara Hukum seperti yang disebutkan dalam Pasal 1 Ayat (3) Undang-Undang Dasar Tahun 1945 yang berbunyi : "Negara Indonesia adalah Negara Hukum". Artinya segala tingkah laku warga negaranya harus sesuai dengan hukum yang berlaku atau hukum positif atau aturan-aturan lainnya seperti tidak bertentangan dengan undang-undang, norma-norma, kaidah-kaidah, asas-asas dan lain-lain.

Hal ini berlaku umum tanpa terkecuali, diantaranya seperti yang dilakukan oleh anggota Tentara Nasional Indonesia. Sebagaimana ditegaskan dalam Pasal 27 ayat (1) Undang-Undang Dasar Tahun 1945 menyatakan : "Setiap warga negara bersamaan kedudukannya di dalam hukum dan 
pemerintahan dan wajib menjunjung hukum dan pemerintahan itu dengan tidak ada kecualinya".

Agar dapat mempermudah dalam proses penelitian, penulis mencoba menggunakan beberapa teori seperti Teori Negara Hukum, Teori Keadilan, Teori Kedisiplinan, dan Teori Hukum Pembangunan.

\section{Teori Negara Hukum}

Teori merupakan pengetahuan ilmiah yang mencakup penjelasan mengenai suatu faktor dari sebuah disiplin ilmiah. Dalam dunia ilmu, teori menempati kedudukan penting, karena teori memberikan sarana untuk dapat merangkum serta memahami masalah yang dibicarakan secara lebih baik. Hal-hal yang semula tampak tersebar dan berdiri sendiri dapat disatukan dan ditunjukkan kaitannya satu sama lain secara lebih bermakna.?

Indonesia adalah negara yang berdasarkan atas hukum menurut Pasal 1 ayat (3) Undang-Undang Dasar Negara Republik Indonesia 1945. Pasal ini menghendaki bahwa penyelenggaraan pemerintahan didasarkan atas prinsipprinsip hukum untuk membatasi kekuasaan pemerintah dan ini artinya kekuasaan negara melalui aparatnya dibatasi oleh hukum (rechtsstaat), bukan didasarkan atas kekuasaan (machtsstaat). ${ }^{8}$

Konsep negara hukum bersandar pada keyakinan bahwa kekuasaan negara harus dijalankan atas dasar hukum yang adil dan baik. Hubungan antara yang diperintah (governed) dan memerintah (governor) dijalankan berdasarkan suatu norma objektif, bukan pada suatu kekuasaan absolut semata-mata. Norma objektif tersebut harus memenuhi syarat formal dan dapat dipertahankan oleh ide hukum.

Negara hukum mensyaratkan bahwa setiap tindakan dari negara haruslah bertujuan untuk menegakkan kepastian hukum, dilakukan secara setara, menjadi unsur yang mengesahkan demokrasi, dan memenuhi tuntutan akal budi. Alat-alat negara mempergunakan kekuasaannya hanya sejauh berdasarkan hukum yang berlaku dan dengan cara yang ditentukan dalam hukum itu. Dalam negara hukum, tujuan suatu perkara adalah agar dijatuhi putusan sesuai dengan kebenaran. Tujuan suatu perkara adalah untuk memastikan kebenaran, maka semua pihak berhak atas pembelaan atau bantuan hukum. ${ }^{9}$

\section{Teori Keadilan}

Definisi keadilan dapat dipahami sebagai suatu nilai (value) yang digunakan untuk menciptakan hubungan yang seimbang antar manusia dengan memberikan apa yang menjadi hak seseorang dengan prosedur dan bila terdapat pelanggaran terkait keadilan maka seseorang perlu diberikan hukuman. Salah satu asas dalam hukum yang mencerminkan keadilan yaitu asas equality before the law yaitu asas yang menyatakan bahwa semua orang sama kedudukannya dalam hukum. ${ }^{10}$

\footnotetext{
${ }^{7}$ Koentjaraningrat, Metode-Metode Penelitian Masyarakat, Gramedia Pustaka Utama, hlm. 21

${ }^{8}$ Oemar Seno Adji, Prasarana Dalam Indonesia Negara Hukum, Simposium UI Jakarta, 1966, hlm. 24.

${ }^{9} \mathrm{Https}: / /$ id.wikipedia.org/wiki/Negara_hukum di akses pada tanggal 31 Oktober 2019.

${ }^{10}$ Munir Fuady, Dinamika Teori Hukum, Ghalia Indonesia, Bogor, 2010, hlm. 91.
} 
Keadilan menurut hukum atau yang sering dimaksud dalam keadilan hukum (legal justice) adalah keadilan menurut undang-undang dan berkenaan dengan pemberian sanksi atas hasil penerapan undang-undang yang dilanggar. Hal ini menunjukkan bahwa jika seseorang telah melanggar keadilan tersebut, maka akan dikenakan hukuman lewat proses hukum. ${ }^{11}$

Hukum diciptakan agar setiap individu anggota masyarakat dan penyelenggara negara melakukan sesuatu tindakan yang diperlukan untuk menjaga tatanan sosial dan mencapai tujuan kehidupan bersama atau sebaliknya agar tidak melakukan suatu tindakan yang dapat merusak tatanan keadilan. Setiap pelanggaran akan mendapatkan sanksi sesuai dengan tingkat pelanggaran itu sendiri. Hukum mewujudkan sebuah nilai karena ia merupakan sebuah norma. Hukum mewujudkan tatanan nilai sekaligus nilai moral, dan itu hanya bermakna bilamana hukum dipandang sebagai sebuah norma. ${ }^{12}$

\section{Teori Kedisiplinan}

Disiplin adalah sistem ajaran mengenai kenyataan atau gejala-gejala yang dihadapi. Dalam hal ini hukum dalam arti disiplin melihat hukum sebagai gejala dan kenyataan yang ada di tengah masyarakat. Apabila pembicaraan dibatasi pada disiplin hukum, maka secara umum disiplin hukum menyangkut ilmu hukum, politik hukum dan filsafat hukum.

a. Ilmu hukum, intinya merupakan ilmu pengetahuan yang berusaha menelaah hukum.

b. Politik hukum, mencakup kegiatan-kegiatan mencari dan memilih nilainilai dan menerapkan nilai-nilai tersebut bagi hukum dalam mencapai tujuannya.

c. Filsafat hukum, adalah perenungan dan perumusan nilai-nilai, juga mencakup penyesuaian nilai-nilai, misalnya penyerasian antara ketertiban dengan ketentraman, antara kebendaan dengan keakhlakan, dan antara kelanggengan dengan pembaharuan. ${ }^{13}$

Sebagimana telah dikemukakan di atas, disiplin hukum merupakan sistem ajaran yang menyangkut kenyataan atau gejala-gejala hukum yang ada dan hidup di tengah pergaulan masyarakat.

Kedisiplinan merupakan suatu hal yang sangat mutlak dalam kehidupan manusia, karena seorang manusia tanpa disiplin yang kuat akan merusak sendi-sendi kehidupannya, yang akan membahayakan dirinya dan manusia lainnya, bahkan alam sekitarnya.

Disiplin merupakan tatanan keteraturan dalam bersikap, berpola dan perilaku yang didasari oleh kesadaran dan keinsyafan pribadi. Disiplin dari kata discere dapat diartikan sebagai tingkah laku yang bersesuaian dengan aturan-aturan perilaku dalam suatu kelompok tertentu. Dalam pengertian lain, disiplin dapat dimaknai sebagai kepatuhan terhadap peraturan atau sikap batin yang bertujuan mengembangkan diri agar dapat berperilaku dengan benar dan tertib.

${ }^{11}$ I Dewa Gede Atmadja, Filsafat Hukum, Setara Press, Malang, 2013, hlm. 87.

12 Hans Kelsen, Teori Hukum Murni, Nusa Media, Penerjemah: Raisul Mutaqien, Bandung, 2014, hlm. 75. hlm. 43 .

${ }^{13}$ Soedjono Dirdjosisworo, Pengantar Ilmu Hukum, PT. Raja Grafindo Persada, Jakarta, 
Dalam organisasi militer, permasalahan kedisiplinan merupakan hal pokok yang sangat mendasar, sehingga karenanya pengaturan tentang disiplin dinormakan dalam bentuk undang-undang. Sebagai norma dasar kemiliteran, hukum disiplin militer tidak hanya norma tertulis saja, tetapi juga didalamnya terdapat nilai-nilai tidak tertulis yang dijadikan landasan kehidupan militer.

Disiplin militer mengatur dan mengarahkan agar seorang Militer selalu berada pada tatanan budaya hukum dan mekanisme perilaku yang berlaku di lingkungan militer, terutama dalam menjaga keseimbangan antara hak dan kewajiban pada satu sisi, dan kepentingan tugas-tugas kemiliteran pada sisi lainnya. Keseimbangan ini melahirkan pemahaman yang bersifat kultural, bahwa mekanisme kehidupan dalam kemiliteran dijalankan atas keteraturan norma-norma yang telah melembaga sebagai bentuk pengakuan dan penghormatan terhadap supremasi hukum. Pada akhirnya kedisiplinan ini diharapkan mampu untuk menjauhkan diri dari sikap dan perilaku arogan serta rasa superior atas komponen bangsa lainnya. ${ }^{14}$

4. Teori Hukum Pembangunan

Teori Hukum Pembangunan Mochtar Kusumaatmadja memakai kerangka acuan pada pandangan hidup masyarakat serta bangsa Indonesia yang meliputi struktur, kultur, dan substansi, yang sebagaimana dikatakan oleh Lawrence F. Friedman. Pada dasarnya memberikan dasar fungsi, hukum sebagai sarana pembaharuan masyarakat, dan hukum sebagai suatu sistem yang sangat diperlukan bagi bangsa Indonesia sebagai Negara yang sedang berkembang.

Menurut Mochtar Kusumaatmadja, hukum diharapkan agar berfungsi lebih daripada itu yakni sebagai "sarana pembaharuan masyarakat" dengan pokokpokok pikiran sebagai berikut :

"Hukum merupakan sarana pembaharuan masyarakat didasarkan kepada anggapan bahwa adanya keteraturan atau ketertiban dalam usaha pembangunan dan pembaharuan itu merupakan suatu yang diinginkan atau dipandang (mutlak) perlu. Anggapan lain yang terkandung dalam konsepsi hukum sebagai sarana pembaharuan adalah bahwa hukum dalam arti kaidah atau peraturan hukum memang bisa berfungsi sebagai alat (pengatur) atau sarana pembangunan dalam arti penyalur arah kegiatan manusia ke arah yang dikehendaki oleh pembangunan dan pembaharuan". ${ }$

Berpijak pada Teori Hukum Pembangunan Mochtar Kusumaatmadja bahwa peranan hukum bisa menjadi alat yang bersifat memaksa untuk perubahan yang lebih baik di masyarakat, sehingga siapapun pelaku pelanggaran termasuk anggota Tentara Nasional Indonesia terhadap peraturan yang ada bisa secara paksa untuk melakukan perubahan kearah yang lebih baik.

\section{E. Metode Penelitian}

Penelitian dipandang sebagai kegiatan formal, sebuah prosedur baku, yang (secara umum) dikatakan sebagai alat pencari data melalui suatu proses untuk menambah pengetahuan pada kerangka pengetahuan

${ }^{14}$ A.S.S. Tambunan, Hukum Disiplin Militer Suatu Kerangka Teori, Pusat Studi Hukum Militer, STHM, Jakarta, 2013, hlm. 55.

15 Yuoky Surinda, https://yuokysurinda.wordpress.com/2016/02/27/ teori-hukumpembangunan-mochtar-kusumaatmadja 
seseorang, dan diharapkan juga terjadi pada orang lain, lewat penemuan fakta dan wawasan yang sesungguhnya.

Untuk dapat mengetahui dan membahas suatu permasalahan maka diperlukan adanya pendekatan dengan menggunakan metode-metode tertentu yang bersifat ilmiah. Menurut Soerjono Soekanto mengatakan bahwa :

"Penelitian adalah suatu kegiatan ilmiah yang berdasarkan kepada analisis dan juga konstruksi yang dilakukan secara sistematis, metodologis serta konsisten dengan tujuan untuk mengungkapkan kebenaran sebagai salah satu manifestasi keinginan manusia guna mengetahui apa yang sedang terjadi dan dihadapinya". ${ }^{16}$

Metode penelitian yang akan di gunakan untuk penulisan ini adalah sebagai berikut :

1. Spesifikasi Penelitian

Dalam penulisan usulan penelitian ini menggunakan spesifikasi penelitian deskriptif analisis untuk menuliskan fakta dan memperoleh gambaran berdasarkan judul dan identifikasi masalah, yang menggambarkan peraturan perundang-undangan yang berlaku dikaitkan dengan teori hukum dan praktek pelaksanaan yang menyangkut permasalahan dalam uraian diatas secara sistematis, lengkap dan logis. ${ }^{17}$

\section{Metode Pendekatan}

Metode pendekatan yang akan digunakan dalam penelitian ini adalah pendekatan yuridis normatif. Untuk itu diperlukan penelitian yang merupakan suatu rencana pokok dalam pengembangan ilmu pengetahuan. Menurut Soerjono Soekanto pendekatan yuridis normatif yaitu penelitian hukum yang dilakukan dengan cara meneliti bahan pustaka atau data sekunder sebagai bahan dasar untuk diteliti dengan cara mengadakan penelusuran terhadap peraturan-peraturan dan literatur-literatur yang berkaitan dengan permasalahan yang diteliti. ${ }^{18}$

3. Tahap Penelitian

Tahap penelitian yang digunakan yaitu studi pustaka (literatur/dokumen) dan penelitian lapangan.

a. Studi pustaka

Yaitu penelitian yang dilakukan untuk mendapatkan data yang bersifat teoritis, dengan mempelajari sumber-sumber bacaan yang berisikan berbagai pengertian dan pendapat para ahli yang erat hubunganya dengan permasalahan dalam penelitian ini.

b. Penelitian lapangan

Penelitian lapangan dimaksudkan untuk memperoleh informasi yang dibutuhkan untuk melengkapi data-data studi pustaka. Data yang diperoleh dari penelitian lapangan ini berupa data dari anggota militer.

4. Teknik Pengumpulan Data

16 Ahmad, https://www.yuksinau.id/ 22_pengertian_penelitian_sosial_menurut_ahli /\#Soerjono Soekanto

17 Ronny Hanitijo Soemitro, Metodologi Penelitian Hukum dan Jurimetri, Ghalia Indonesia, Jakarta, 1994, hlm. 57.

18 Soerjono Soekanto \& Sri Mamudji, Penelitian Hukum Normatif (Suatu Tinjauan Singkat), Rajawali Pers, Jakarta, 2001, hlm. 13-14. 
Teknik pengumpulan data yang digunakan adalah studi kepustakaan dan observasi langsung.

a. Studi kepustakaan : Teknik ini dilakukan untuk mendapatkan data yang bersifat teoritis, dengan cara inventarisasi data melalui tahap mengumpulkan, mengolah, dan memilih data. Teknik ini juga digunakan untuk memberi arahan dengan mempelajari masalah yang diteliti dari buku-buku, majalah, dan koran yang ada hubungannya dengan masalah yang diteliti.

b. Observasi langsung : Teknik ini dilakukan untuk mengumpulkan, meneliti dan mengolah data yang diperoleh dari lapangan dengan melakukan observasi secara langsung terhadap objek yang di teliti.

5. Alat Pengumpulan Data : Alat pengumpulan data yang digunakan penulis adalah observasi dan wawancara, yaitu melakukan penelitian di Pengadilan Militer II-09 Bandung dan juga melakukan tanya jawab untuk mendapatkan data secara langsung dari responden yang terkait dengan masalah.

6. Analisis Data : Analisis data yang digunakan dalam penelitian ini adalah yuridis kualitatif yang bertujuan untuk menggambarkan implementasi penegakan hukum pidana militer menurut Undang-Undang Nomor 31 Tahun 1997 tentang Peradilan Militer terhadap oknum Tentara Nasional Indonesia yang memfasilitasi pelaku tindak pidana Narkotika.

7. Lokasi Penelitian

Dalam penyusunan Usulan Penelitian ini berlokasi di tempat yang mempunyai korelasi dengan masalah yang dikaji oleh peneliti, yaitu :

a. Perpustakaan Universitas Majalengka

b. Perpustakaan Fakultas Hukum Universitas Majalengka

c. Perpustakaan Daerah Kabupaten Majalengka

d. Pengadilan Militer II-09 Bandung, Jl. Soekarno Hatta No. 745, Cisaranten Endah, Arcamanik, Kota Bandung, Jawa Barat 40265

\section{F. Pembahasan Penegakan Hukum Pidana Terhadap Oknum TNI yang Memfasilitasi Pelaku Tindak Pidana Narkotika.}

\section{Prosedur Penegakan Hukum Pidana Militer Terhadap Oknum TNI Yang Memfasilitasi Pelaku Tindak Pidana Narkotika}

Mengenai prosedur dalam penyelesaian perkara militer sendiri memiliki tahapan yang sama dengan perkara umum, tahapan tersebut meliputi, tahap penyidikan, penuntutan, pemeriksaan di depan pengadilan, dan yang terakhir adalah tahap eksekusi. Namun dilingkup peradilan militer, dalam setiap tahap tersebut memiliki ciri khas yang menandakan kekhasan dari peradilan militer itu sendiri. Misalnya dalam proses penyidikan, tidak hanya dilakukan oleh Polisi Militer akan tetapi penyidikan dapat juga dilakukan oleh Oditur, Ankum (atasan yang berhak menghukum). Dan dapat pula dilakukan oleh kepolisian atau pegawai negeri sipil yang diberikan kewenangan oleh Undang-Undang untuk melakukan penyidikan. Kolonel CHK (K) Nanik Suwarni, S.H., M.H. selaku Hakim Pengadilan Militer II-09 Bandung mengungkapkan mengenai keadaan penegak hukum dalam lingkup militer saat ini : "Penegakan hukum saat ini sudah mengikuti perkembangan yang sesuai tuntutan masyarakat. Dalam hal lain juga disebabkan karena 
peradilan militer berada dibawah naungan Mahkamah Agung dan adanya dukungan penuh mengenai penegakan hukum dilingkup militer sendiri termasuk diantaranya penegakan hukum bagi anggota yang melakukan tindak pidana narkotika". Akan tetapi dalam kenyataannya masih belum efektif dan terdapat beberapa kendala dalam proses penegakan hukum pidana militer tersebut.

Dalam tahapan pemeriksaan perkara tindak pidana narkotika terdapat ketentuan yang harus diperhatikan, karena di dalam peradilan militer berlaku beberapa jenis peradilan yang telah ditentukan perannya masing-masing. Kepala Pengadilan Militer sebagai penentu dalam pemeriksaan, apakah ini termasuk wewenang Pengadilan Militer ataukah Pengadilan Tinggi Militer. Kewenangan Pengadilan Militer untuk mengadili ada pada anggota militer yang berpangkat Kapten kebawah, sedangkan Pengadilan Militer Tinggi mengadili tingkat pertama terdakwa yang berpangkat Mayor keatas dan mengadili tingkat kedua perkara banding dari pengadilan militer. Pada tahapan pemeriksaan persidangan, Kolonel CHK (K) Nanik Suwarni, S.H., M.H. selaku Hakim Pengadilan Militer II-09 Bandung mengungkapkan bahwa : "Pada tahapan pemeriksaan didepan pengadilan dengan perkara narkotika memakai acara pemeriksaan biasa namun dilaksanakan secara cepat dan secara keseluruhan hampir sama dengan proses-proses pemeriksaan yang lain dalam Pengadilan Militer. Selain dari pada itu terhadap pemeriksaan dilakukan suatu penilaian terhadap fakta-fakta yang terungkap didalam persidangan". Keterlibatan upaya memfasilitasi peredaran narkotika sebagaimana terungkap dalam kasus No. 064-K/PM.II-09/AU/III/2-17 pada Peradilan Militer Bandung, dilakukan oleh oknum TNI yang memfasilitasi terjadinya tindakan kejahatan penyalahgunaan narkotika yang dilakukan oleh JTJ sebagai anggota Tentara Nasional Indonesia berpangkat SERMA. Tututan Oditur Militer kepada JTJ terdakwa telah terbukti secara sah dan meyakinkan bersalah melakukan tindak pidana penyalahgunaan narkotika golongan 1 . Bahwa JTJ menjadi prajurit TNI AU sejak tahun 1999, pada awalnya JTJ selaku terdakwa dalam kasus ini mendapatkan narkotika jenis golongan 1 tersebut dari temannya yang berinisal $A B$ yang pada awalnya $A B$ hanya memberi secara cuma-cuma kepada JTJ untuk menghisap atau menggunakan narkotika jenis golongan 1 tersebut, bahwa pada tanggal 30 November tahun 2016 sekira pukul 22.00 WIB JTJ menelpon temannya (pemakai) dengan tujuan untuk menawarkan sabu-sabu (narkotika jenis golongan 1) dengan harga Rp.450.000,- dengan jumlah sabu $+1 / 4$ gr. Perkara tersebut diatas telah memenuhi unsur Pasal 18 Undang-Undang No. 35 Tahun 2009 tentang Narkotika menyatakan, bahwa : "Permufakatan Jahat adalah perbuatan dua orang atau lebih yang bersekongkol atau bersepakat untuk melakukan, melaksanakan, membantu, turut serta melakukan, menyuruh, menganjurkan, memfasilitasi, memberi konsultasi, menjadi anggota suatu organisasi kejahatan Narkotika, atau mengorganisasikan suatu tindak pidana Narkotika." 19

Adapun proses peradilan bagi anggota militer yang melakukan tindak pidana tidak murni dilaksanakan pada peradilan militer sebagaimana diatur dalam Undang-Undang Nomor 31 Tahun 1997 tentang Peradilan Militer, memperkuat keberadaan Peradilan Militer sebagaimana yang tercantum dalam Pasal 8 Ayat 1 dan 2 yang menyatakan : “(1) Pengadilan dalam

${ }^{19} \mathrm{Http}: / /$ repository.unpas.ac.id/50108/1/8.\%20BAB\%20I\%20ANTO.pdf 
lingkungan peradilan militer merupakan badan pelaksana kekuasaan kehakiman di lingkungan Angkatan Bersenjata. (2) Pelaksanaan kekuasaan kehakiman sebagaimana dimaksud pada ayat (1) berpuncak pada Mahkamah Agung sebagai Pengadilan Negara Tertinggi". Dalam hal terjadinya tindak pidana yang dilakukan oleh oknum TNI, maka Polisi Militer wajib melakukan tindakan penyidikan sesuai dengan tatacara dan prosedur yang diatur dalam Kitab Undang-Undang Hukum Acara Pidana (KUHAP) dan Undang-Undang Nomor 31 Tahun 1997 tentang Peradilan Militer. Pasal 69 Undang-Undang Nomor 31 tahun 1997 tentang Peradilan Militer : Penyidik adalah : ${ }^{20}$

1. Para Ankum Terhadap anak buahnya (Ankum).

2. Polisi Militer (POM).

3. Jaksa-Jaksa Militer di lingkungan Peradilan Militer (Oditur Militer).

Dengan demikian Polisi Militer adalah salah satu upholder of Law didalam lingkungan militer. Sesuai fungsi Polisi Militer yang merupakan fungsi teknis, secara langsung turut menentukan keberhasilan dalam pembinaan TNI maupun penyelenggaraan operasi Hankam. Selain itu untuk meningkatkan kesadaran hukum, disiplin dan tata tertib yang merupakan syarat utama dalam kehidupan prajurit yang tercermin dalam sikap perilaku, tindakan dan pengabdiannya maka diperlukan pengawasan secara ketat dan berlanjut.

\section{Tabel I. Penyelesaian Pelanggaran Hukum Disiplin Tidak Murni}

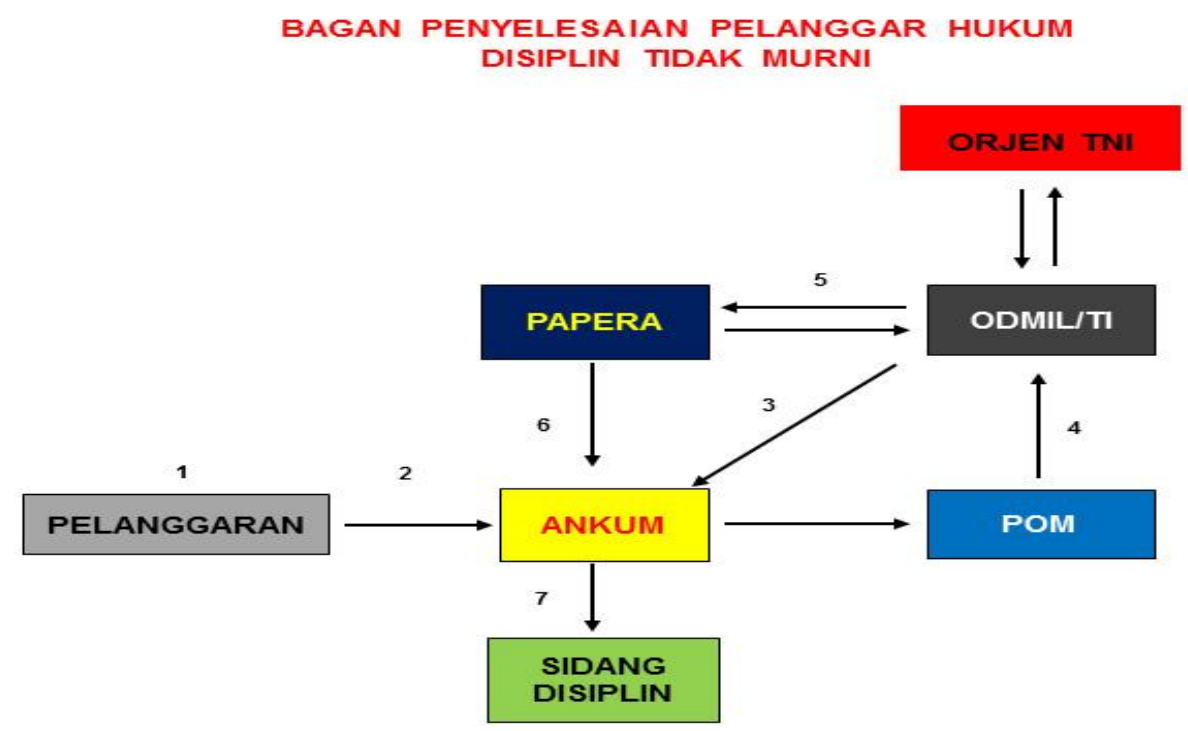

Terjadi pelanggaran oleh prajurit TN I :

1. Dilaporkan kepada Ankum.

2. Karena perbuatan tersebut tindak pidana, Ankum menyerahkan ke POM.

3. Hasil penyidikan oleh POM diserahkan ke Odmil/ti.

4. Surat Pendapat Hukum Odmil/ti disarankan kepada Papera untuk didisiplinkan.

5. Papera tanda tangani Skep tentang penyelesaian menurut hukum disiplin dan kemudian diserahkan kepada Ankum untuk segera gelar sidang disiplin.

6. Ankum menyelenggarakan sidang hukuman disiplin. 
PRESUMPTION of LAW

\section{Faktor Yang Menyebabkan Oknum TNI Memfasilitasi Peredaran Narkotika}

Tindak pidana narkotika berdasarkan Undang-Undang Nomor 35 Tahun 2009 tentang Narkotika memberikan sanksi pidana cukup berat, di samping dapat dikenakan hukuman badan dan juga dikenakan pidana denda, tapi dalam kenyataanya tindak pidana Narkotika di dalam masyarakat menunjukkan kecenderungan yang semakin meningkat baik secara kuantitatif maupun kualitatif dengan korban yang meluas, terutama di kalangan anakanak, remaja, dan generasi muda pada umumnya bahkan sampai kepada anggota militer.

Faktanya bahwa banyak orang pada zaman sekarang sudah banyak terlibat kasus narkotika bahkan bukan masyarakat umum saja bahkan sampai kepada anggota militer pernah terlibat kasus tersebut. Beberapa faktor yang menyebabkan oknum TNI memfasilitasi peredaran narkotika $:^{21}$

1. Faktor pribadi, yaitu mental yang lemah yang menyebabkan goyah dan mudah terpengaruh ajakan keburukan. Mental yang sepertinya selalu merasa sendiri dan tersingkirkan, tidak memiliki tanggungjawab, kurang mampu bergaul dengan baik.

2. Faktor keluarga, yaitu kurangnya keharmonisan dalam keluarga, jika terjadi suatu konflik dalam keluarga dimana masalah tersebut terlalu sulit untuk diselesaikan sehingga menimbulkan depresi, hal ini dapat memicu seseorang untuk menggunakan narkoba agar dapat merasakan suatu ketenangan dan jauh dari masalah yang dialami.

3. Faktor ekonomi merupakan akar dari permasalahan dari setiap tindak kejahatan. Seseorang akan melakukan hal-hal yang melanggar hukum jika tidak terpenuhinya kebutuhan hidup mereka, termasuk oknum TNI sekalipun. Tingginya kebutuhan hidup memaksa oknum TNI untuk mencari pendapatan tambahan melalui berbagai cara termasuk menyalahgunakan kewenangan mereka untuk hal-hal yang seharusnya mereka berantas seperti, menerima suap, melindungi pengedar narkoba bahkan ikut menggunakan dan mengedarkan narkoba. Hal ini semata mereka lakukan hanya untuk memenuhi kebutuhan hidup mereka dan keluarga mereka.

Tidak adanya suatu pendirian yang tetap dalam suatu kepribadian akan menyebabkan seseorang mudah terpengaruh oleh hal-hal negatif khususnya penyalahgunaan narkotika. Sebab pada pribadi yang semacam ini, biasanya tidak dapat membedakan hal-hal yang positif dan negatif. Krisis kejiwaan juga memegang peranan yang penting, hal ini biasanya terjadi pada orang-orang yang kurang kreatif, pemalas, senang ikut-ikutan, senang iseng. Keadaan seperti ini akan menimbulkan perbuatan yang negatif, sebab orangorang semacam ini tidak dapat memanfaatkan waktu yang luang dengan kegiatan positif.

Selain itu banyak faktor yang dapat menyebabkan seseorang mulai menyalahgunakan narkotika, sehingga pada akhirnya dapat menyebabkan ketergantungan. Pada umumnya secara keseluruhan faktor-faktor yang menyebabkan seseorang melakukan tindak pidana narkotika dapat dibedakan

${ }^{21}$ Ni Made Desy Dwi H, https://core.ac.uk/download/pdf/77630645.pdf 
atas faktor internal dan faktor eksternal. Faktor internal merupakan faktor yang berasal dari dalam diri sendiri, sedangkan faktor eksternal merupakan merupakan faktor yang berasal dari luar diri pelaku.

1. Faktor Internal

Faktor internal sebagai faktor yang berasal dari dalam diri sipelaku yang berupa :

a. Faktor Usia

Kebanyakan penyalahgunaan narkotika dan psikotropika dimulai atau terdapat pada masa remaja, sebab masa remaja yang sedang mengalami perubahan biologik, psikologik maupun sosial yang pesat merupakan individu yang rentan untuk menyalahgunakan narkotika maupun psikotropika tersebut. Akan tetapi dalam lingkup militer kebanyakan penyalahgunaan narkotika dilakukan oleh oknum TNI yang sebentar lagi pensiun, dikarenakan pada masa tersebut digunakan oleh para oknum TNI untuk menambah penghasilan.

b. Faktor Pendidikan

Banyak oknum TNI yang terlibat dalam kasus narkotika ini hanya lulusan SMA sederajat. Sehingga pemahaman mereka tentang bahaya narkoba tidak diketahui dengan baik. Sosialisasi tentang bahaya narkoba juga tidak pernah mereka dapatkan. Baik di sekolah maupun di lingkungan masyarakat. Pendidikan yang rendah mengakibatkan daya tangkap menjadi kurang dan pada akhirnya pelaku memiliki pengetahuan yang terbatas pula.

c. Faktor Psikologis

Secara individu terdapat beberapa faktor yang mempengaruhi seseorang dapat menyalahgunakan narkotika dan psikotropika. Alasan ini merupakan alasan yang bersumber dari diri sendiri atau pemakai narkotika dan pasikotropika tersebut yakni sebagai berikut :

1) Rasa kecewa, frustasi, kesal

Perasaan kesal, kecewa, atau frustasi biasanya terjadi karena kegagalan pada generasi muda, eksekutif muda, suami atau istri. Penggunaan narkotika dan psikotropika pada kelompok ini bertujuan untuk sesaat melupakan kekecewaan, kekesalan dan frustasi. Kondisi masyarakat yang carut marut telah banyak melahirkan kekecewaan, kekesalan, bahkan frustasi. Narkotika dan psikotropika dapat melupakannya sesaat, tetapi tidak untuk mengatasi masalah yang sesungguhnya.

2) Ingin bebas dari rasa sakit atau pusing

Penderita penyakit berat yang kronis dan tidak kunjung sembuh, misalnya kanker hati, luka bakar, luka tusuk, wasir, kanker paru-paru, migren, encok, pengapuran, dan lain-lain, selalu merasakan sakit yang luar biasa karena penyakitnya. Rasa sakit tersebut sering kali tidak dapat dihilangkan dengan obat penghilang rasa sakit biasa (analgetik) sehingga penderitanya mencoba narkotika atau psikotropika. Narkotika maupun psikotropika dapat menghilangkan rasa sakit tersebut, tetapi tidak menyembuhkan penyakitnya. Celakanya, pemakai yang bersangkutan malah mendapat masalah baru yaitu ketergantungan dengan segala komplikasinya yang justru menjadi lebih berbahaya. 
2. Faktor Eksternal

Faktor eksternal yang menyebabkan terjadinya Tindak Pidana Narkotika terdiri dari :

a. Faktor Keluarga

Faktor keluarga merupakan hal yang penting pada terjadinya penggunaan awal obat-obatan terlarang. Keluarga mempunyai peranan penting dalam perkembangan awal serta melindungi dari awal penggunaan narkoba. Jika terjadi suatu konflik dalam keluarga dimana masalah tersebut terlalu sulit untuk diselesaikan sehingga menimbulkan depresi, hal ini dapat memicu seseorang untuk menggunakan narkoba agar dapat merasakan suatu ketenangan dan jauh dari masalah yang dialami.

b. Faktor Ekonomi

Faktor ekonomi merupakan akar dari permasalahan dari setiap tindak kejahatan. Seseorang akan melakukan hal-hal yang melanggar hukum jika tidak terpenuhinya kebutuhan hidup mereka, termasuk oknum TNI sekalipun. Tingginya kebutuhan hidup memaksa oknum TNI untuk mencari pendapatan tambahan melalui berbagai cara termasuk menyalahgunakan kewenangan mereka untuk hal-hal yang seharusnya mereka berantas seperti, menerima suap, melindungi pengedar narkoba bahkan ikut menggunakan dan mengedarkan narkoba. Hal ini semata mereka lakukan hanya untuk memenuhi kebutuhan hidup mereka dan keluarga mereka.

\section{Upaya Yang Dilakukan Oleh Ankum Dalam Mengatasi Oknum TNI Yang Memfasilitasi Pelaku Tindak Pidana Narkotika}

Proses penyelesaian perkara pidana militer terbagi atas beberapa tahapan yang meliputi tahap penyidikan, penuntutan, pemeriksaan di Pengadilan Militer dan berakhir dengan proses eksekusi. Adanya tahapantahapan tersebut terkait pula dengan pembagian tugas dan fungsi dari berbagai institusi dan satuan penegak hukum di lingkungan TNI yang pengaturan kewenangannya adalah sebagai berikut :

1. Komandan satuan selaku Ankum dan atau Papera.

2. Polisi Militer sebagai Penyidik.

3. Oditur Militer selaku penyidik, penuntut umum dan eksekutor.

4. Hakim Militer di Pengadilan Militer yang mengadili memeriksa dan memutus perkara pidana yang dilakukan oleh Prajurit TNI atau yang dipersamakan sebagai Prajurit TNI menurut Undang-Undang.

Ditinjau dari perannya dalam fungsi penegakan hukum militer, menurut Undang-Undang Nomor 26 tahun 1997 tentang Hukum Disiplin Prajurit Pasal 1 Ayat 9 mengatakan "Atasan yang Berhak Menghukum yang selanjutnya disingkat Ankum adalah atasan yang oleh atau atas dasar Undang-Undang ini diberi kewenangan menjatuhkan hukuman disiplin kepada setiap prajurit Angkatan Bersenjata Republik Indonesia yang berada di bawah wewenang komandonya".

Dalam hal bentuk pelanggaran hukum tersebut merupakan Tindak Pidana, maka Komandan-Komandan tertentu yang berkedudukan setingkat Komandan Korem dapat bertindak sebagai Perwira Penyerah Perkara atau 
Papera yang oleh Undang-Undang diberi kewenangan menyerahkan perkara setelah mempertimbangkan saran pendapat Oditur Militer. Saran pendapat hukum dari Oditur Militer ini disampaikan kepada Papera berdasarkan berita acara pemeriksaan hasil penyidikan Polisi Militer.

Hak komando dari pada komandan diperolehnya dari delegasi yang berasal dari pucuk pimpinan Angkatan Bersenjata, sedangkan hak untuk menghukum anak buahnya diatur dalam Hukum Disiplin Militer Bab VII Ankum dan kewenangannya. Komandan harus dapat mengarahkan, mengkoordinir, dan mengendalikan tugasnya dengan sempurna, karena apabila salah satu wewenang tersebut tidak ada maka ketentraman ketertiban pasukan akan kacau, karena berarti salah satu wewenang itu berada dipihak lain dengan kata lain adanya turut campur pihak luar terhadap keutuhan suatu pasukan. Oleh karena itu wewenang itu tidak boleh lepas dari wewenang seorang komandan, agar dapat memelihara disiplin pasukannya dan untuk dapat melaksanakan tugas pokoknya dengan baik.

\section{G. Kesimpulan}

1. Mengenai prosedur dalam penyelesaian perkara militer, yang pertama ketika terjadi pelanggaran langsung dilaporkan kepada Ankum (atasan yang berhak menghukum), lalu Ankum menyerahkan ke POM, hasil penyidikan oleh POM diserahkan ke Oditur Militer, kemudian surat pendapat Odmil di sarankan kepada Papera (perwira penyerah perkara) untuk didisiplinkan, Papera membuat Skep tentang penyelesaian hukum disiplin dan kemudian diserahkan kepada Ankum untuk gelar siding disiplin.

2. Faktor yang menyebabkan oknum TNI memfasilitasi peredaran Narkotika, yaitu :

a. Faktor pribadi, yaitu mental yang lemah yang menyebabkan goyah dan mudah terpengaruh ajakan keburukan.

b. Faktor keluarga, yaitu kurangnya keharmonisan dalam keluarga, jika terjadi suatu konflik dalam keluarga dimana masalah tersebut terlalu sulit untuk diselesaikan sehingga menimbulkan depresi, hal ini dapat memicu seseorang untuk menggunakan narkoba agar dapat merasakan suatu ketenangan dan jauh dari masalah yang dialami.

c. Faktor ekonomi, tingginya kebutuhan hidup memaksa oknum TNI untuk mencari pendapatan tambahan melalui berbagai cara termasuk menyalahgunakan kewenangan mereka untuk hal-hal yang seharusnya mereka berantas.

3. Di dalam Undang-Undang Nomor 26 tahun 1997 tentang Hukum Disiplin Prajurit Pasal 1 Ayat 9 mengatakan "Atasan yang Berhak Menghukum yang selanjutnya disingkat Ankum adalah atasan yang oleh atau atas dasar Undang-Undang ini diberi kewenangan menjatuhkan hukuman disiplin kepada setiap prajurit Angkatan Bersenjata Republik Indonesia yang berada di bawah wewenang komandonya". 


\section{H. Saran}

1. Pertama, sebaiknya para penegak hukum dilingkup militer kususnya Polisi Militer melakukan Penyuluhan hukum di satuan agar dapat memberikan pemahaman kepada anggota militer tentang bagaimana hukum yang berlaku dalam lingkup militer. Kedua, memberikan kewenangan yang lebih kepada Polisi Militer dalam hal penyelidikan dan penyidikan sehingga dapat melakukan penegakan hukum secara cepat dan efektif. Ketiga, perlunya wadah dalam lingkup militer untuk menampung laporanlaporan dari masyarakat terhadap perilaku anggota militer agar dapat melakukan penegakan hukum secara cepat.

2. Pemberlakuan hukuman berupa eksekusi mati bagi gembong-gembong narkoba, serta beragam tindakan tegas seperti instruksi tembak mati bandar narkoba yang melakukan perlawanan saat akan ditangkap, kian menegaskan urgensi efek narkoba.

3. Komandan/atasan yang berhak menghukum (Ankum) harus dapat mengarahkan, mengkoordinir, dan mengendalikan tugasnya dengan sempurna agar dapat memelihara disiplin pasukannya dan untuk dapat melaksanakan tugas pokoknya dengan baik. 


\section{DAFTAR PUSTAKA}

\section{A. Sumber Buku}

A.S.S. Tambunan, Hukum Disiplin Militer Suatu Kerangka Teori, Pusat Studi Hukum Militer, STHM, Jakarta, 2013. , Hukum Militer Indonesia Suatu Pengantar, Pusat Studi Hukum Militer, STHM, Jakarta, 2005.

Abdul Mukthie Fadjar, Sejarah, Elemen dan Tipe Negara Hukum, Setara Press, Malang, 2016.

Amirroedin sjarif, Disiplin Militer dan Pembinaannya, Ghalia Indonesia, Jakarta, 1982.

Andi Hamzah, Asas-Asas Hukum Pidana, Rineka Cipta, Jakarta, 2001. Hukum Acara Pidana Indonesia, Jakarta : Sinar Grafika, 2010.

Asmah, Pengantar Hukum Indonesia, suatu pemahaman awal mengenai hukum, UII Press, Yogyakarta, 2018.

Barda Nawawi Arief, Kebijakan Hukum Pidana, PT. Citra Aditya Bakti, Bandung, 2002.

Carl Joachim Friedrich, Filsafat Hukum Perspektif Historis, Nuansa dan Nusamedia, Bandung, 2004.

Chairudin dan Dkk, Starategi Pencegahan dan Penegakan Hukum Tindak Pidana Korupsi, PT Refika Aditama, Bandung, 2009.

Dini Dewi Haniarti, Sistem Peradilan Militer di Indonesia, Bandung, 2017.

E. Utrecht, Pengantar Hukum Administrasi Negara, Ichtiar Baru, Jakarta, 1985.

Gatot Supramono, Hukum Narkoba Indonesia, Djambatan, Jakarta, 2007.

Hans Kelsen, Teori Hukum Murni, Nusa Media, Penerjemah: Raisul Muttaqien, Bandung, 2014. , General Theory of Law and State, Penerjemah: Raisul Muttaqien, Nusa Media, Bandung, 2011.

HM Rasyid Ariman, Fahmi Raghib, Hukum Pidana, Malang : Setara Press, 2015.

I Dewa Gede Atmadja, Filsafat Hukum, Setara Press, Malang, 2013.

John Rawls, A Theory of Justice, London: Oxford University press, diterjemahkan oleh Uzair Fauzan dan Heru Prasetyo, Teori Keadilan, Pustaka Pelajar, Yogyakarta, 2006.

Julie Andrews, Discipline, dalam Shelia Ellison and Barbara An Barnet Ph.D, 365 Ways to help your Children Grow, Sourcebook, Naperville, Illinois, 1996.

Koentjaraningrat, Metode-Metode Penelitian Masyarakat, Gramedia Pustaka Utama.

L. J. Van Apeldoorn, Pengantar Ilmu Hukum, Cetakan Kedua Puluh Enam Pradnya Paramita, Jakarta, 1996.

Mardjono Reksodipuro, Kriminologi dan Sistem Peradilan Pidana Kumpulan Karangan Buku Kedua, Pusat Pelayanan Keadilan dan Pengabdian Hukum Lembaga Kriminologi Universitas Indonesia, Jakarta.

Moch. Faisal Salam, Hukum Pidana Militer di Indonesia, Mandar Maju, Bandung, 2006.

Peradilan Militer Indonesia, Mandar Maju, Bandung, 2004. 
Mochtar Kusumaatmadja, Konsep-Konsep Hukum dalam Pembangunan Nasional, Penerbit Alumni, Bandung, 2002. , Pembinaan Hukum Dalam Rangka Pembangunan Nasional, Bina Cipta, Bandung, 1975.

Mohammad Taufik Makarao, Tindak Pidana Narkotika, Ghalia Indonesia, Jakarta, 2003.

Mokhammad Najih, Politik Hukum Pidana Konsepsi Pembaharuan Hukum Pidana Dalam Cita Negara Hukum, Setara Press, Malang, 2014.

Munir Fuady, Dinamika Teori Hukum, Ghalia Indonesia, Bogor, 2010.

Oemar Seno Adji, Prasarana Dalam Indonesia Negara Hukum, Simposium UI Jakarta, 1966.

Pan Mohamad Faiz, Teori Keadilan John Rawls, dalam Jurnal Konstitusi, Volume 6 Nomor 1, 2009.

Ronny Hanitijo Soemitro, Metodologi Penelitian Hukum dan Jurimetri, Ghalia Indonesia, Jakarta, 1994.

Santoso Sastropoetra, Partisipasi, Komunikasi, Persuasi dan Disiplin dalam Pembangunan Nasional, Penerbit: Alumni, Bandung.

Soedjono Dirdjosisworo, Pengantar Ilmu Hukum, PT. Raja Grafindo Persada, Jakarta, 2003.

Soegeng Prijodarminto, Disiplin Kiat Menuju Sukses, Pradanya Paramita, Jakarta, 1994.

Soerjono Soekanto \& Sri Mamudji, Penelitian Hukum Normatif (Suatu Tinjauan Singkat), Rajawali Pers, Jakarta, 2001.

, Faktor-Faktor Yang Mempengaruhi Penegakan Hukum, UI Pres, Jakarta, 1983.

Suhadi, Pembahasan Perkembangan Pembangunan Hukum Nasional Tentang Militer dan Bela Negara, Badan Pembinaan Hukum Nasional Tentang Hukum Militer dan Bela Negara, Jakarta, 1996.

Suhrawardi K. Lunis, Etika Profesi Hukum, Cetakan Kedua, Sinar Grafika, Jakarta, 2000.

Teguh Prasetyo, Rule Of Law Dalam Dimensi Negara Hukum Indonesia, dalam Jurnal Ilmu Hukum Refleksi Hukum Edisi Oktober 2010.

\section{B. Sumber Peraturan Perundang-undangan}

Undang-Undang Dasar Negara Republik Indonesia Tahun 1945.

Undang-Undang Nomor 3 Tahun 2002 tentang Pertahanan Negara.

Undang-Undang Nomor 25 Tahun 2014 tentang Hukum Disiplin Militer.

Undang-Undang Nomor 31 Tahun 1997 tentang Peradilan Militer.

Undang-Undang Nomor 34 Tahun 2004 tentang Tentara Nasional Indonesia.

Undang-Undang Nomor 35 Tahun 2009 tentang Narkotika.

Undang-Undang Nomor 48 Tahun 2009 tentang Kekuasaan Kehakiman.

Kitab Undang-Undang Hukum Pidana Militer.

\section{Sumber Lain}

Ahmad, 22 Pengertian Penelitian Sosial Menurut Ahli, https:// www.yuksinau.id/22-pengertian-penelitian-sosial-menurutahli/\#Soerjono_Soekanto di akses pada tanggal 31 Oktober 2019.

https://id.wikipedia.org/wiki/Negara_hukum di akses pada tanggal 31 Oktober 2019. 
Junaidi Maulana, http://junaidimaulana.blogspot.com/2013/02/budayahukum-dan-penegakan-hukum23.html di akses pada tanggal 25 November 2019.

Nur Fatin, http://seputarpengertian.blogspot.com/2016/05/pengertianpengadilan-militer.html di akses pada tanggal 25 November 2019.

Yuoki Surinda, Teori Hukum Pembangunan Mochtar Kusumaatmadja, https://yuoky surinda.wordpress.com/2016/02/27/teori-hukumpembangunan-mochtar-kusumaatmadjal di akses pada tanggal 31 Oktober 2019. 